\title{
The Relationship Among Motivation, The Implementation Of Learning Approaches and Students' Performance: A Study From Accounting Education Students
}

\author{
Ulfa Nurhayani $^{1^{*}}$, Andri Zainal ${ }^{2}$, Rini Herliani ${ }^{3}$ \\ ${ }^{1,2,3}$ Faculty of Economics, Universitas Negeri Medan, Indonesia \\ *andrizainal@unimed.ac.id
}

\begin{abstract}
Extant studies highlight that different motivation and learning approach contributes to the different result of study outcomes. This condition reflects in students in Accounting Education Department where they experienced two learning approaches namely: Deep Learning and Surface Learning applied during the completion of their study in the respective university. In students' batch of 2015 where they refer to the blockcurriculum mechanism assuming that students in this batch are in the stream of surface learning. Likewise, students above the 2016 batches are practicing deep learning approach following the implementation of six (6) assignments under KKNI namely: regular assignment, critical book report, critical journal report, mini research, project and idea engineering embedded in each of subjects in the curriculum. This study is set to ascertain the influence of motivation and both learning approaches on students' performances in both batches. Based on the data collection from 142 students using questionnaires that further tested with a multiple regression analysis method, it is found that students' motivations and learning approaches influence the students' performance positively and significantly. The study confirms relevant prior research and the Social Constructivism Theory to the extent that students' collaboration in various learning activities the have engaged both in and outside classrooms complement the outcome of surface learning approach toward stepping the deep learning one.
\end{abstract}

Keywords: Learning Approach, Deep Learning Approach, Surface Learning Approach, Motivation, Students' Performance

\section{Introduction}

In the learning process, learning achievement is the final part of the learning process or in other words the purpose of learning is to get good achievements. Many factors affect learning achievement, one of which is motivation. Students with high motivation will find it easier to achieve what is expected in learning activities. Students who have high motivation, both from themselves and others eventually will foster enthusiasm, excitement and pleasure in learning. This will have an impact on increasing student's learning achievement. With the motivation in each lecture process, students will also follow the lecture process well and drive to continue learning better which will have an impact on student achievement.

Another factor that influences learning achievement is the learning approach. In order for the learning process to be effective, a lecturer is required to be able to apply a variety of 
appropriate approaches, because the learning approach is needed to provide opportunities for students in order to obtain an optimal learning experience. The learning approach chosen is expected to be a learning approach that allows and emphasizes material and solves problems that are learned independently.

More specifically, learning approaches can be defined as cognitive, affective and psychosocial characteristics that function as relatively stable indicators of how students perceive, interact and respond to the learning environment [1]. This is supported by the social constructivism theory proposed by Vygotsky that states that the learning process is shaped by the surrounding social environment [2]. For example if a student is in an environment that has a high level of competition then he will be encouraged to get good results by studying seriously so that he can understand all the material being taught, conversely if a student is in an environment that has a high level of competition low, then he will be lazy to learn and learn even just to get grades and the important thing can go to the next stage, he just memorizes the material without getting an understanding of the material.

The learning approach or often called Approach to Learning was first put forward by Marton and Saljo in 1976 who conducted research in Sweden using qualitative methods, they grouped the learning approach into 2 types, namely deep learning and surface learning. Furthermore, this research continues to be developed by other researchers, such as Jhon Biggs. Jhon Biggs did a lot of research on the Deep Learning Approach and Surface Learning Approach and to some extent, especially for researchers in this loop, called this approach as the Jhon Biggs approach. Biggs and Tang [3] and Biggs et al. [4] describe "the surface learning approach as an intention only to gain enough knowledge, the knowledge obtained is used only to complete assignments or pass examinations". This approach aims to avoid failure in learning but with minimal effort. Students who apply this approach tend to focus on memorizing material without getting an understanding of the material they are memorizing. Meanwhile Biggs et al. [4] posits "the deep learning approach as an intention instilled from within to commit to gaining knowledge and understanding in depth material". Students who apply this approach will think analytically and try to connect the knowledge gained with the knowledge previously obtained.

Universitas Negeri Medan (UNIMED) has now implemented the KKNI curriculum for each generation except the 2015 class. This also applies to students of the 2016 class in accounting and accounting education courses. With this KKNI curriculum-based, there are many tasks faced from starting Critical Book Review (CBR), Critical Journal Review (CJR), routine assignments, mini research, projects, and engineering ideas to make students have a learning process that takes up a lot of their time in doing the task. The existence of this KKNI curriculum makes students have a long learning time so that each of their learning has a different learning approach such as the surface learning approach and the deep learning approach. Student learning approaches have variations in applying the learning approach to learning in the classroom and outside the classroom.

This study aims to find examine the effect of motivation and learning approaches on learning performance of students in the 2015 and 2016 batches. Class of 2015 is a non-KKNI curriculum based while the 2016 class is the first class that applies KKNI curriculum-based. The result of this study brings interesting findings with regards to the application of different learning approaches in learning systems from two batches of students that applies different curriculum-based. This research is also important to the extent of determining the consistency of the social constructivism theory and prior study conducted by Everaert et al. [5] from the study performed in a developing country. 


\section{Literature Review}

Achievement is an outcome obtained by individuals or groups. Each individual or group would want a good achievement, to get a good achievement requires the ability, skills and tenacity in carrying out an activity. If related to learning activities, learning achievement is the final result obtained through expertise, ability and skills through optimal effort. Based on the theory of social constructivism, the process of understanding in teaching and learning activities depends on the learner himself, how he sees a topic in learning and what motivations influence it so that it will have an impact on learning achievement to be obtained. For example, students who are in an environment with a high level of competition will also have a high motivation from within themselves to obtain optimal learning achievement so as to be able to get the best rank among others, conversely if someone is in an environment with a low level of competition, then he will also be carried away by the atmosphere, he will have low motivation to learn and do the task just because the demands are only and most importantly pass and can continue to the next stage.

Learning Motivation is one of the factors that influence learning activities. Motivation in learning is anything that gives impetus (psychology, feelings, and emotions) and directs someone to act or do something in accordance with is a process to arouse, maintain, and control the interests of impulse within to achieve a goal. In addition, the Learning Motivation that exists in students so that students can follow the process of implementing the learning program well and more quickly understand the accounting subjects that are being taught $/$ delivered. Teaching and learning activities will succeed well if students are diligent in doing the task, the tenacity of students in solving problems and obstacles independently so that later in the end students will get an appreciation, namely in the form of achieving good Learning Achievements. If students have high learning motivation then their academic performance can also be achieved to the maximum level. Likewise, if students have low learning motivation then learning performance of students will follow suit.

A student who has tenacity, ability and good skills in the learning process will get a good learning achievement as well. Student achievement is also influenced by several factors, one of which is motivation. Schunk et al. [6] define "motivation as the process that evokes and maintains functional behavior". Motivation itself is divided into 2, namely intrinsic motivation and extrinsic motivation. Intrinsic motivation refers to the willingness to complete certain tasks and there is a sense of satisfaction in being able to complete them [7]. This reflects personal goals that come from within and interest in the material. Meanwhile extrinsic motivation is guided by external goals in completing tasks, for example only to get grades. It is strongly influenced by appreciation and pressure from outside, for example someone wants to do a job because it is lured by certain rewards [8]. According to Saljo [5] "someone who is highly motivated tends to apply deep learning to his learning activities". Besides that someone who has intrinsic motivation learns from curiosity, interest or satisfaction [5]. The same thing was said by Donald [5] that states "intrinsic motivation leads to a deep learning approach". Someone with high motivation in learning and has a desire to be able to master all the material being taught will definitely get a high learning achievement. Meanwhile according to Tang [5] "students who have extrinsic motivation in doing their work in learning tend to adopt a surface learning approach."

Along with motivation, the learning approach is a way to manage learning activities and student behavior so that he/she can actively carry out learning tasks in achieving instructional goals for a particular instructional unit so as to obtain optimal learning achievement. The learning approach in this case is divided into two namely the deep learning approach and the 
surface learning approach. The approach of deep learning is an approach to learning that is done by better understanding a material not just memorizing it when it will take an exam, in contrast to the surface learning approach that is more memorizing a material. The learning approach influences the achievement of learning achievement both the deep learning approach and the surface learning approach.

In particular, the result of a study conducted by [5] indicates that accounting students had slightly higher scores for the deep learning approach compared to the surface learning approach. In addition, high intrinsic motivation and extrinsic motivation have a significant positive effect on the deep learning approach. Furthermore, learning leads to higher academic performance; surface-learning approach on the other hand leads to lower academic performance. Deep learning approach has significant effect on academic achievement when entering the duration of learning variables underlining a higher motivation to study than their peers who use the surface learning one.

In the accounting related department attached to the university, it is very important for students to practice the principles in accounting by continuing to do a lot of practice, do it gradually and learn with a lot of time [5]. This is in accordance with the explanation from Scully \& Kerr "students report that they receive a heavy burden and high time pressure in the accounting department". According to Biggs and Tang [3] "students who apply the deep learning approach have an interest and are always actively involved in doing their work". Students who apply a deep learning approach really want to understand the material as a whole, not just knowing and memorizing the material. Therefore, this research formulates the research hypothesis that motivation and the implementation of deep learning approach and surface learning approach influence the students' performance in the accounting education department of Faculty of Economics of UNIMED.

\section{Research Method}

The population of this study is all students of Accounting Education Study Program class of 2015 and 2016. The details of the population can be seen in the following table:

Table 1. Population of the Study

\begin{tabular}{|c|c|c|}
\hline Batch & Class & Number of Students \\
\hline \multirow{4}{*}{2015} & A & 25 \\
\hline & B & 31 \\
\hline & $\mathrm{C}$ & 25 \\
\hline & $\mathrm{D}$ & 28 \\
\hline \multirow{3}{*}{2016} & $\mathrm{~A}$ & 38 \\
\hline & B & 38 \\
\hline & $\mathrm{C}$ & 36 \\
\hline \multicolumn{2}{|c|}{ Total } & 221 \\
\hline
\end{tabular}

From the total of 221 respondents, we then use the Slovin's formula to generate the number of representative samples resulting 142 samples from both batches of students. The survey instrument using questionnaires were distributed to the respective number of respondents who were selected purposively from the three classes from each batch. Prior to do so, we performed validity and reliability checks using Pearson correlation for the construct 
validity and Cronbach's alpha of internal-consistency coefficient respectively. The result of tests shows there is no issue in the construct validity and reliability among items presented in the questionnaire.

To test hypotheses, we conduct the multiple regression analysis that requires several procedures of tests before applying the respective regression analysis. The procedures are widely known as assumption tests consisted of normality, linearity, heteroscedasticity, autocorrelation and multi co-linearity tests that must be no issue presented prior performing the regression analysis [10].

\section{Results and Discussion}

\section{a. Descriptive Statistic of Variables}

The data presented in this study were obtained from a questionnaire and also documentation of Grade Point Average (GPA) of accounting education students from batches of 2015 and 2016. The variables in this study are motivation to learn (notated with X1) and learning approaches (notated with X2). Both of learning motivation and learning approaches are independent variables. The dependent variable is the learning achievement indicated by the accounting education students' GPA of the 2015 and 2016 batches (notated by Y). The presentation of the descriptive statistic data from each variable can be seen as follow:

\section{Motivation $\left(\mathbf{X}_{1}\right)$}

Results data regarding the learning motivation of 2015 and 2016 batches of accounting education students in the economics faculty of UNIMED were obtained from questionnaire answers given to 142 respondents. After the instrument has been tested for validity and reliability, there are 25 items of statements that must be filled honestly by respondents. Subsequently, the observed responses are processed using the SPSS Version 21 program resulting the highest score of 125, the lowest score of 84, the Mean of 103,950 , the median is 104 , and the mode or is 107 .

\section{Learning Approaches $\left(\mathbf{X}_{2}\right)$}

In contrast to learning motivation, after being tested for validity and reliability the learning approach is represented by 20 statement items, so that the total statement is 45 items. The data regarding the results of the 2015 and 2016 batches of accounting education students in the economics faculty of UNIMED. The result of descriptive statistic show the highest score of 92 , the lowest score of 65, the Mean of 78.993, the median of 78, and the mode is 78 .

\section{Learning Achievement (Y)}

Data regarding learning achievements used in this study were sourced from the cumulative achievement index of all respondents of the 2015 and 2016 accounting education students of the Faculty of Economics, State University of Medan, the value used at this university was a scale of 4 , then the data presented also used a scale of 4 . After all the data to be analyzed are presented, the next step before testing the hypothesis is to conduct the classical assumption tests accordingly.

The normality test is used to determine whether the data obtained from the research results are normally distributed or not. A data is confirmed to have normal distribution if the significance level $>0.05$, whereas if the significance level $<0.05$ then the data is said to be not 
normally distributed. If the data is normally distributed, it will be analyzed by parametric statistical tests (Product Moment Correlation Analysis). Meanwhile, if the data are not normally distributed, according to the discussion in the previous chapter, it will be analyzed by non-parametric static tests (Kendall's Correlation Test and Spearman).

Table 2. The Result of Normality Test

\begin{tabular}{lrrrrrr}
\hline & \multicolumn{3}{c}{ Kolmogorov-Smirnov ${ }^{\mathrm{a}}$} & \multicolumn{3}{c}{ Shapiro-Wilk } \\
& Statistic & df & \multicolumn{1}{c}{ Sig. } & Statistic & df & Sig. \\
\hline Motivation & .075 & 142 & .274 & .988 & 142 & .256 \\
Learning Approaches & .146 & 142 & .217 & .952 & 142 & .177 \\
Students' Performance & .541 & 142 & .137 & .201 & 142 & .103 \\
\hline a. Liliefors Significance Correlation & & & & & &
\end{tabular}

From the results of the normality test as shown on Table 2 above, the following conclusions can be drawn:

- Data on the learning achievement variable (Y) has a significance value of 0.137 greater than 0.05 , so the data are declared normally distributed.

- Data on learning motivation variables (X1) have a significance value of 0.274 greater than 0.05 , so the data are declared normally distributed.

- Data on the learning approach variable (X2) has a significance value of 0.217 greater than 0.05 , so the data is declared to be normally distributed.

Subsequently, the linearity test aims to determine whether two variables have a linear relationship or not significantly. This test is usually used as a prerequisite in correlation analysis or linear regression. Testing on SPSS using Test for Linearity with a significance level of 0.05 . Two variables are said to have a linear relationship if the significance (linearity) is less than 0.05 .

Tabel 3. The Result of Linearity Test (ANOVA Table)

\begin{tabular}{|c|c|c|c|c|c|c|c|}
\hline & & & $\begin{array}{l}\text { Sum of } \\
\text { Squares }\end{array}$ & df & $\begin{array}{l}\text { Mean } \\
\text { Square }\end{array}$ & $\mathrm{F}$ & Sig. \\
\hline \multirow{6}{*}{$\begin{array}{l}\text { Motivation * } \\
\text { Students' } \\
\text { Performance }\end{array}$} & Between & (Combined) & 3,946 & 34 & ,116 & 1,689 & ,008 \\
\hline & Groups & & & & & & \\
\hline & & Linearity &, 542 & 1 &, 542 & 8,727 & ,004 \\
\hline & & $\begin{array}{l}\text { Deviation from } \\
\text { Liniearity }\end{array}$ & 3,404 & 33 & 103 & .661 &, 027 \\
\hline & $\begin{array}{l}\text { Within } \\
\text { Groups }\end{array}$ & & 6,643 & 107 & ,062 & & \\
\hline & Total & & 10,588 & 141 & & & \\
\hline
\end{tabular}

From the results of the linearity test as shown on the Table 3 generated a significant value of 0.027 which is less than 0.05 confirming that the data is linier.

The next procedure is conducting the autocorrelation test which is used to determine whether there is a correlation between the confounding variable at a certain period with the previous variable. For time series data autocorrelation often occurs. But for data whose sample cross-section rarely occurs because the confounding variables are different from one another. In detecting autocorrelation using Durbin-Watson (D-W) values with criteria if: 
- The score of D-W below -2 means there is a positive autocorrelation,

- The score of D-W between -2 and +2 means there is no autocorrelation, and

- The score of $\mathrm{D}-\mathrm{W}$ above +2 means there is a negative correlation.

Tabel 4. The Result of Auto-Correlation Test Model Summary ${ }^{\mathrm{b}}$

\begin{tabular}{|c|c|c|c|c|c|c|c|c|}
\hline \multirow[t]{2}{*}{ Model } & \multirow[t]{2}{*}{$\mathrm{R}$} & \multirow[t]{2}{*}{$\begin{array}{c}\mathrm{R} \\
\text { Square }\end{array}$} & \multirow[t]{2}{*}{$\begin{array}{l}\text { Adjusted } \\
\text { R Square }\end{array}$} & \multirow{2}{*}{$\begin{array}{l}\text { Std/ } \\
\text { Error of } \\
\text { the } \\
\text { Estimate }\end{array}$} & \multicolumn{3}{|c|}{ Change Statistics } & \multirow[t]{2}{*}{$\begin{array}{l}\text { Durbin- } \\
\text { Watson }\end{array}$} \\
\hline & & & & & $\begin{array}{c}\text { R } \\
\text { Square } \\
\text { Change }\end{array}$ & $\begin{array}{ccc}\mathrm{F} & \mathrm{df} 1 & \mathrm{df} 2 \\
\text { Change } & & \end{array}$ & $\begin{array}{l}\text { Sig. F } \\
\text { Change }\end{array}$ & \\
\hline 1 & $274^{\mathrm{a}}$ &, 075 & ,062 & 26543 & 075 & 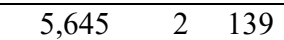 & ,004 & 1,874 \\
\hline
\end{tabular}

a. Predictors: (Constant), Motivation, Learning Approaches

b. Dependent Variable" Students' Performance

The result shows that the Durbin-Watson value of 1.8874 is found between the values of -2 and +2 , so it is said that there is no positive auto correlation.

In term of the multi co-linearity that is intended to determine whether there is a similarity between independent variables. The similarity between independent variables will result in a very strong correlation. Besides this test is also to avoid the habit in the decision-making process regarding the effect of the partial test of each independent variable on the dependent variable. Tolerance and VIF produced between 1-10 will not occur multi co-linearity.

Table 5. The Result of Multi co-linearity Test Coefficients ${ }^{\mathrm{a}}$

\begin{tabular}{|c|c|c|c|c|c|c|c|c|}
\hline & \multirow[t]{2}{*}{ Model } & \multicolumn{2}{|c|}{$\begin{array}{c}\text { Unstandardized } \\
\text { Coefficients }\end{array}$} & \multirow{2}{*}{$\begin{array}{c}\text { Standardized } \\
\text { Coefficients }\end{array}$} & \multirow[b]{2}{*}{$\mathrm{t}$} & \multirow[b]{2}{*}{ Sig. } & \multicolumn{2}{|c|}{$\begin{array}{c}\text { Collinearity } \\
\text { Statistics }\end{array}$} \\
\hline & & B & $\begin{array}{l}\text { Std. } \\
\text { Error }\end{array}$ & & & & Tolerance & VIF \\
\hline \multirow[t]{3}{*}{1} & Constant & 3,132 & 269 & & 11,646 & ,000 & & \\
\hline & Motivation &, 008 &, 002 & ,360 & 4,542 &, 000 & 999 & 1,001 \\
\hline & $\begin{array}{l}\text { Learning } \\
\text { Approaches }\end{array}$ &, 000 &, 003 &,- 010 &,- 126 & ,900 & ,999 & 1,001 \\
\hline
\end{tabular}

From the test, the tolerance variable of motivation and learning approach is obtained with the same value of $1.00>0.1$, so it is said that there is no multi co-linearity. Just like the tolerance value, the VIF value for the motivation variable and the learning approach are also the same that is $1,00<10,0$ so it is said that there is no multi co-linearity.

Lastly, the heteroskedasticity test was conducted to examine the difference in residual variance of one observation period to another observation period. How to predict the presence or absence of heteroskedasticity in a model can be seen with the Scatterplot pattern, regression that does not occur heteroscedasticity if the data points spread above and below or around zero, the data points do not collect just above or below it, the spread of points - points data may not form wavy patterns then widen and then narrow and widen again, the spread of data points is not patterned. 


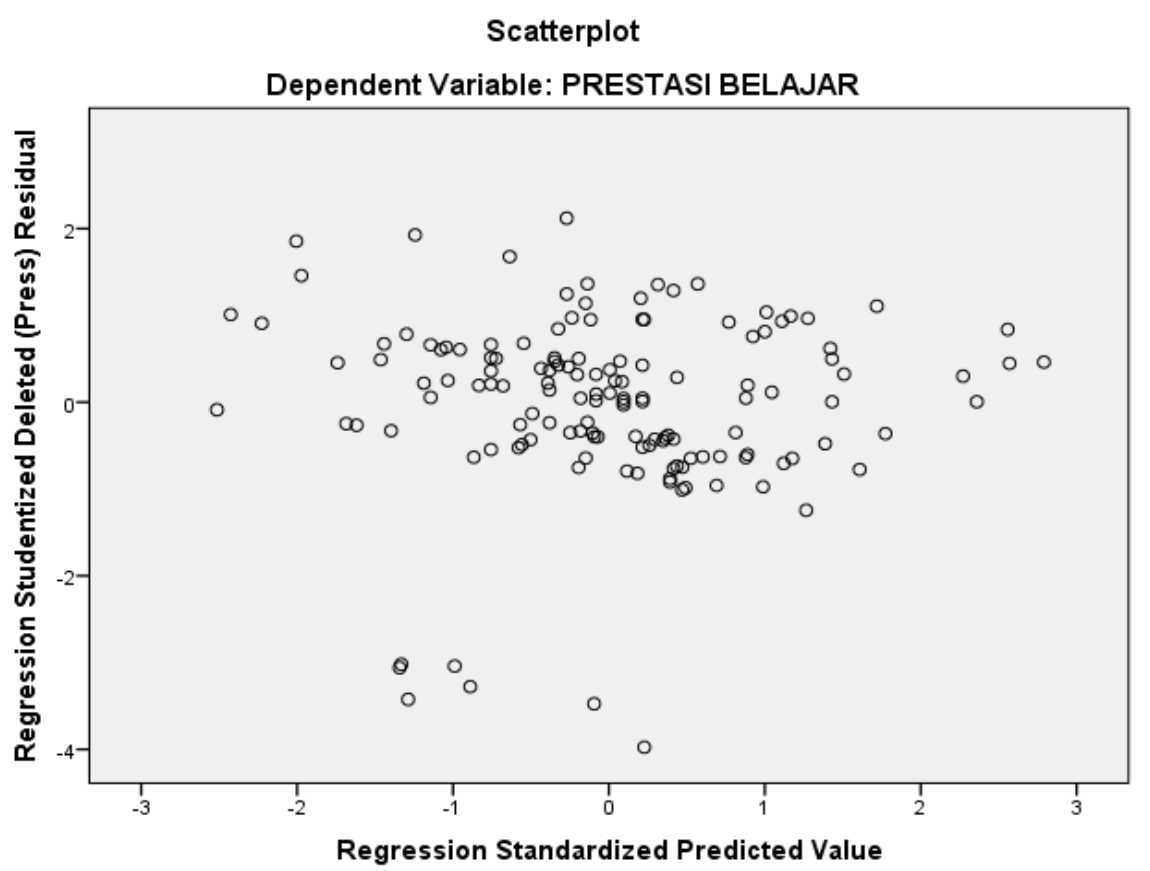

Fig 1. The Scatterplot Pattern

From the image shown in the Scatterplot pattern show a spread pattern of points indicating that the heteroscedasticity does not occur. Thus, with no single issue is found among classical assumption tests, the multiple regression analysis can be conducted accordingly.

\section{b. Multiple Regression Analysis}

In testing the hypothesis of this study, multiple linear regression techniques were used. This hypothesis test was used to determine the influence of motivation (X1), learning approaches (X2) on students' performance (Y) from Accounting Education Study Program batches of 2015 and 2016 in Faculty of Economics, UNIMED.

Table 6. The Result of Multiple Regression Test

\begin{tabular}{llrrrrr}
\multicolumn{7}{c}{ Coefficients $^{\mathrm{a}}$} \\
\hline \multirow{2}{*}{ Model } & \multicolumn{1}{c}{$\begin{array}{c}\text { Unstandardized } \\
\text { Coefficients }\end{array}$} & $\begin{array}{c}\text { Standardized } \\
\text { Coefficients } \\
\text { B }\end{array}$ & \multicolumn{1}{c}{ Std. Error } & Beta & t & \multicolumn{1}{c}{ Sig. } \\
\hline \multirow{2}{*}{1} & Constant & 2,041 &, 393 & & 5,188 &, 000 \\
& Motivation &, 007 &, 003 &, 224 & 2,750 &, 007 \\
& Learning Approaches &, 007 &, 003 &, 155 & 1,897 &, 060 \\
\hline
\end{tabular}

a. Dependent Variable: Students' Performance

Based on the result shown in the Table 6, the motivation has a significant value of 0.007 which is less than 0.05 meaning that the hypothesis is supported. The variable of learning motivation has a significant effect on the students' performance variable. Whereas the 
implementation of learning approaches has a significant value of 0.060 which is slightly greater than 0.05 . This result rejects the hypothesis indicating that the implementation learning approaches in students batches of 2015 and 2016 does not significantly influence the Accounting Education students' performance.

Furthermore, to find out the influence of motivation variables and learning approaches on students' performance can be analyzed from the result presented in the following table:

Table 7.

Table 7. The Result of F-Test ANOVA ${ }^{\mathrm{a}}$

\begin{tabular}{llrrrrr}
\hline Model & \multicolumn{1}{c}{$\begin{array}{c}\text { Sum of } \\
\text { Squares }\end{array}$} & df & $\begin{array}{c}\text { Mean } \\
\text { Square }\end{array}$ & F & \multicolumn{1}{c}{ Sig. } \\
\hline 1 & Regression &, 795 & 2 &, 398 & 5,645 &, $004^{\mathrm{b}}$ \\
& $\begin{array}{l}\text { Residual } \\
\text { Total }\end{array}$ & 9,793 & 139 &, 070 & &, 007 \\
& 10,588 & 141 &, & &, 060 \\
\hline
\end{tabular}

a. Dependent Variable: Students' Performance

b. Predictors: (Constant), Motivation, Learning Approaches

Based on the table above, the significant value is $0.004<0.05$, which means that the hypothesis is accepted, which means that the motivation variable and the learning approaches variable have a significant effect together on the students' performance variable indicated from the F-test can assess multiple coefficients simultaneously. Both motivational and learning approaches variables together have a significant effect on learning achievement where the significant value is $0.004<0.05$. The effect of motivation and learning approaches on students' performance simultaneously is equal to $27.4 \%$. Judging from the magnitude of the effect, the value can be interpreted as low. There are still $72.6 \%$ of other factors that affect learning achievement. Many things can affect learning achievement as revealed by number of scholars. To name a few is Muhibbinsyah [9] that globally, apart from the implementation of learning approaches there are factors that influence students' performance. They are: (1) internal factors (factors from within students), including two aspects namely: a) physiological aspects, consisting of: the sense of hearing and the sense of sight, b) psychological aspects, consisting of: student intelligence, student attitudes, student talents, student interests, and student motivation; (2) external factors (factors from outside students), namely the environmental conditions around students. This includes two aspects, namely: a) social environment, consisting of the school environment, the community, neighbors, and parents, b) non-social environment, consisting of: school buildings and their location, homes and locations, learning tools, weather conditions and study time.

\section{Conclusion}

Based on the results of research and discussion that has been described, it can be concluded that there is a significant influence of students' motivation, learning approaches on students' performance from accounting education department batches of 2015 and 2016. Even though, in general the result of the study still confirms the social constructivism theory highlighting the importance of embedding internal motivation from students towards achieving a good learning achievement; the results of this study differ from studies conducted by Everaert et al. [5] to the extent that there is no impact of learning approaches on learning 
achievement.

This difference is likely due to no separation of observation in each learning approach (deep learning and surface learning approaches) for each batch who applying different learning approach reflected from the different application of curriculum-based.

Thus, the future research in this area can do a further study that distinguishing the application of learning approach in both observation and analysis. It is also recommended to accommodate several factors as suggested by Muhibbinsyah [9] toward presenting a higher predictive value on students' performance.

\section{References}

[1] Oktaria, D. Peranan Pendekatan Belajar dalam Pendidikan Kedokteran. Jurnal Agromedicine, 4 (2), 342-347. ISSN:2346-332x. (2018).

[2] Christensen, J., Dkk. Implementing Team-Based Learning (TBL) In Accounting Courses. Accounting Education, 28 (2), 1-25. ISSN: 0963-9284. (2018)

[3] Biggs, J., dan Tang, C. Teaching for quality learning at university (3rd ed.) Dalam Dejene, W. Dkk. 2018. Preservice teachers' approaches to learning and their teaching approach preferences: Secondary teacher education program in focus. Cogent Education, 5, 1-15. ISSN:2331-186X. (2007).

[4] Biggs, J., Kember, D., dan Leung, D. Y. The revised two-factor study process questionnaire: RSPQ-2F. British Journal of Educational Psychology, 71(1), 133-149. ISSN: 2044-8279. (2001).

[5] Everaert, P., Opdecam, E., \& Maussen, S. The relationship between motivation, learning approaches, academic performance and time spent. Accounting Education, 26(1), 78-107. (2017).

[6] Schunk, D. H., Dkk. Motivation in education: Theory, research, and applications. Upper Saddle River, NJ: Pearson/Merrill Prentice Hall. (2008).

[7] Baker, S. R. Intrinsic, extrinsic, and amotivational orientations: Their role in university adjustment, stress, well-being, and subsequent academic performance. Current Psychology, 23 (3), 189-202. ISSN: 1936-4733. (2004).

[8] Opdecam, E., dan Everaert, P. Improving student satisfaction in a first-year undergraduate accounting course by team learning. Issues in Accounting Education, 27 (1), 53-82. ISSN: 1558-7983. (2012).

[9] Muhibbinsyah. Psikologi Pendidikan Dengan pendekatan Baru. Bandung: Rosda Karya. (2013).

[10] Hair, J. F., Jr., Black, W. C., Babin, B. J., \& Anderson, R. E. Multivariate data analysis (7th ed.). Upper Saddle River, NJ: Prentice-Hall. (2010). 